\title{
Laparoscopic Resection of Large Gastric Gastrointestinal Stromal Tumor - Case Report and Concise Review
}

\author{
Abhijit Shaligram* \\ Department of Surgery, Mayo Regional Hospital, USA
}

Submission: April 17, 2017; Published: April 26, 2017

*Corresponding author: Abhijit Shaligram, Department of Surgery, Mayo Regional Hospital, 891 West Main Street, Dover-Foxcroft, ME 04426, USA, Tel: (207) 564-4464; Fax: (207) 564-4468; Email: abhijit.shaligram@gmail.com

\begin{abstract}
Gastrointestinal stromal tumors (GIST) are relatively rare and commonly involve the stomach. Surgical resection is generally recommended when feasible. Although laparoscopic resection has been used for smaller tumors, resection for larger tumors is less well described. We report a case of gastric $6.5 \mathrm{~cm}$ GIST treated with laparoscopic wedge resection and review the literature.
\end{abstract}

Keywords: Gastrointestinal Stromal Tumor; Laparoscopic resection; Gastric tumors

\section{Introduction}

Gastrointestinal stromal tumors (GIST) are relatively rare tumors affecting the alimentary tract, commonly the stomach. Treatment is surgical resection and laparoscopic resection is being increasingly utilized. We report a case of gastric $6.5 \mathrm{~cm}$ GIST treated with laparoscopic wedge resection.

Case Report

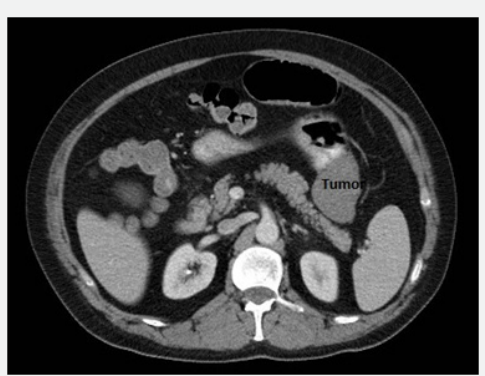

Figure 1: Computed Tomogram of abdomen showing tumor.

53-year-old gentleman was admitted with small bowel obstruction secondary to adhesions. His past medical history was remarkable for left orchiectomy for embryonal cell cancer as well as prior exploratory laparotomy for presumed jejunal intussusception. The Computed Tomogram of the abdomen and pelvis showed an incidental $6 \mathrm{~cm}$ tumor arising from the posterior wall of stomach concerning for GIST (Figure 1). He was initially treated non-operatively for his small bowel obstruction which resolved over the next 24-48 hours. He then underwent further evaluation of this mass in the form of upper endoscopy and endoscopic ultrasound. This revealed hypoechoic $5 \times 5$ $\mathrm{cm}$ mass at $45 \mathrm{~cm}$ from incisors. The endoscopic fine-needle aspiration cytology was performed and on pathology showed spindle cell neoplasm consistent with a GIST. He was counseled about the treatment options and he opted for an attempt at laparoscopic resection.

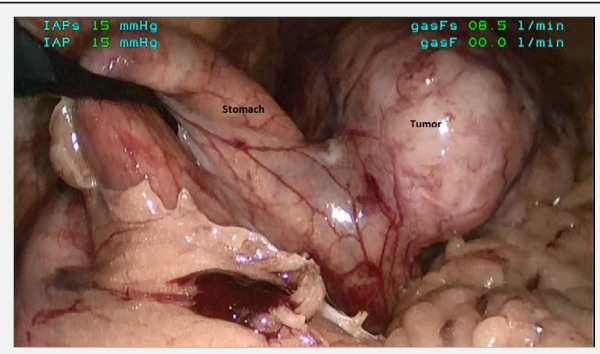

Figure 2: Intra-operative photograph showing the tumor and its attachment to the posterior greater curvature of stomach.

During surgery standard diagnostic laparoscopy was performed. There was no evidence of metastatic disease on laparoscopy. The greater curvature of the stomach was grasped with a Babcock forceps and the short gastric vessels were taken down. The lesser sac was entered. The tumor was encountered in this location attaching to the posterior wall of the gastric fundus (Figure 2). This was about $6 \mathrm{~cm}$ in size. Wedge resection was performed using the endoscopic linear stapling device. The 
tumor was placed in endoscopic retrieval bag and removed. The patient had an uneventful recovery and was discharge home in 48 hours. The final pathology showed $6.5 \mathrm{~cm}$ spindle cell type gastrointestinal stromal tumor, grade 2 (Figures $3 \& 4$ ). The surgical resection margins were negative and there were $>5$ mitoses/50 high power field. This stratified the tumor to high-risk group. On Immunochemistry CD117 was positive and on molecular genetic analysis a mutation in KIT exon 11 was detected. He is now being receiving adjuvant treated with imatinib $400 \mathrm{mg}$ daily and continues to do well at follow up.
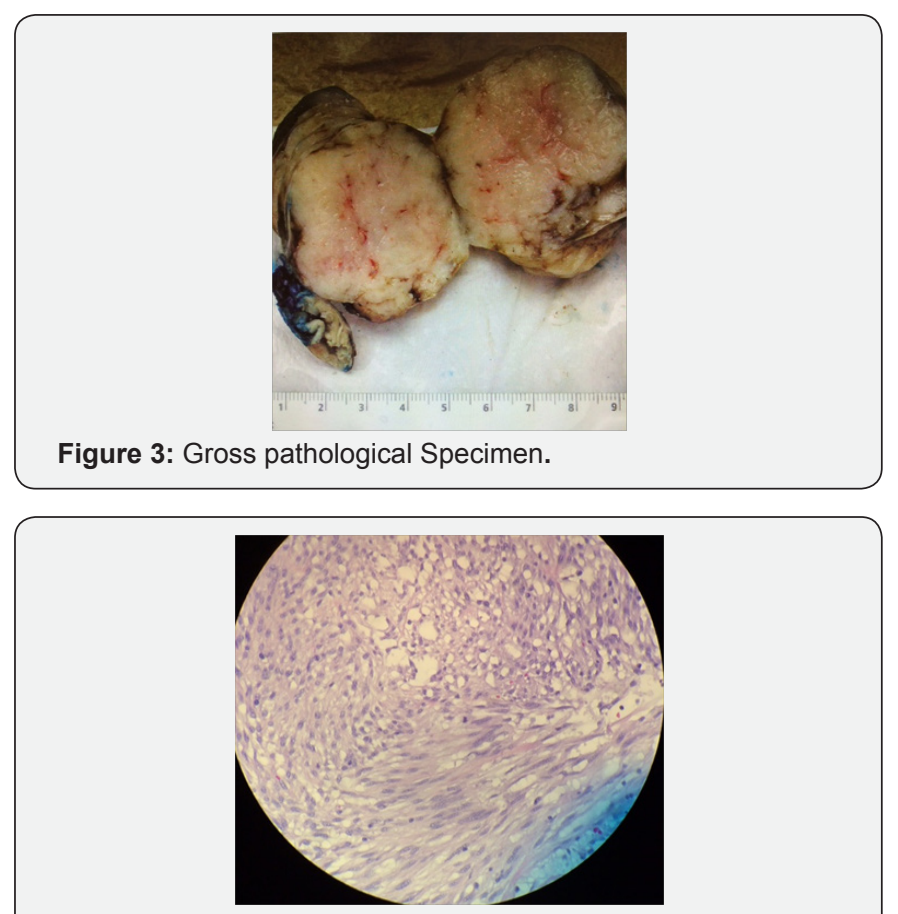

Figure 4:Low power microscopy showing spindle cell neoplasm.

\section{Discussion}

GIST is rare tumors commonly affecting the alimentary tract most commonly the stomach [1]. Gastric GIST is frequently located in the greater curvature and body of the stomach [2]. There are considered malignant tumors and generally thought to spread via direct invasion or hematogenous routes [3]. The malignant potential depends on various variables like size, mitotic activity and location of the tumor within the gastrointestinal tract [4].

The most common symptoms of gastric GISTs are gastrointestinal bleeding and abdominal pain. However, most patients are asymptomatic and the lesions are discovered incidentally during an upper endoscopy or imaging studies performed for other reasons as was in our patient [5]. Crosssectional imaging is helpful in knowing the relations to the surrounding structures and whether local involvement and metastatic disease is present. Upper endoscopy and endoscopic ultrasound provide valuable information for size and location of the tumor [6]. This also have the advantage of sampling the tumor for tissue diagnosis.
The gold standard for these tumors is surgical resection. The goal of treatment is to remove all grossly visible tumor. Since the advent of adjuvant treatments radical surgeries have fallen out of favor and are generally reserved for recurrence or failure of adjuvant treatments. For the gastric GIST tumors the surgical approach is defined by the location [7]. This can be performed both by open and laparoscopic techniques. A minimally invasive approach offers shorter hospital length of stay, early recovery and minimal perioperative complications. The laparoscopic approaches have been successfully employed for smaller tumors less than $5 \mathrm{~cm}$ and more recently been evaluated for larger tumors $[8,9]$.

Studies have confirmed the satisfactory long-term oncologic outcome for laparoscopic techniques compared to open procedures [10]. For the gastric GIST,options for laparoscopic resections include endoscopic and trans-gastric resections, sleeve gastrectomy, wedge resection and distal gastrectomy. Choice for surgery depends on the location of the tumor. In our case the tumor arose from posterior aspect of the greater curvature of the stomach. Hence this was unable to laparoscopic wedge resection. The important surgical principles include "no touch technique" and placing of the endoscopic retrieval bag sooner to avoid spillage of the tumor [1]. We demonstrated successful resection of large gastric GIST tumor with laparoscopic technique. When feasible, minimally invasive approach should be considered even for GIST tumor larger than $5 \mathrm{~cm}$.

\section{References}

1. Novitsky YW, Kercher KW, Sing RF, Heniford BT (2006) Long-term outcomes of laparoscopic resection of gastric gastrointestinal stromal tumors. Ann Surg 243(6): 738-745; discussion 745-747.

2. Matthews BD, Walsh RM, Kercher KW, Sing RF, Pratt BL, et al. (2002) Laparoscopic vs open resection of gastric stromal tumors. Surg Endosc 16(5): 803-807.

3. Chi JL, Xu M, Zhang MR, Li Y, Zhou ZG (2007) Laparoscopic Versus Open Resection for Gastric Gastrointestinal Stromal Tumors (GISTs): A SizeLocation-Matched Case-Control Study. World J Surg

4. Miettinen M, Lasota J (2006) Gastrointestinal stromal tumors: pathology and prognosis at different sites. Semin Diagn Pathol 23(2): 70-83.

5. van der Zwan SM, DeMatteo RP (2005) Gastrointestinal stromal tumor: 5 years later. Cancer 104(9): 1781-1788.

6. Nickl NJ (2004) Gastrointestinal stromal tumors: new progress, new questions. Curr Opin Gastroenterol 20(5): 482-487.

7. Chourmouzi D, Sinakos E, Papalavrentios L, Akriviadis E, Drevelegas A (2009) Gastrointestinal stromal tumors: a pictorial review. J Gastrointestin Liver Dis 18(3): 379-383.

8. MacArthur KM, Baumann BC, Nicholl MB (2017) Laparoscopic Versus Open Resection for Gastrointestinal Stromal Tumors (GISTs). J Gastrointest Cancer 48(1): 20-24.

9. Masoni L, Gentili I, Maglio R, Meucci M, D’Ambra G, et al. (2014) Laparoscopic resection of large gastric GISTs: feasibility and long-term results. Surg Endosc 28(10): 2905-2010.

10. Milone M, Elmore U, Musella M, Parise P, Zotti MC, et al. (2017) Safety and efficacy of laparoscopic wedge gastrectomy for large gastrointestinal stromal tumors. Eur J Surg Oncol 43(4): 796-800. 
This work is licensed under Creative Commons Attribution 4.0 Licens DOI:_10.19080/OAJS.2017.03.555622
Your next submission with Juniper Publishers will reach you the below assets

- Quality Editorial service

- Swift Peer Review

- Reprints availability

- E-prints Service

- Manuscript Podcast for convenient understanding

- Global attainment for your research

- Manuscript accessibility in different formats ( Pdf, E-pub, Full Text, Audio)

- Unceasing customer service

Track the below URL for one-step submission https://juniperpublishers.com/online-submission.php 